\title{
A historiographical approach to Paul Perny's grammar of the Chinese language
}

\author{
Xavier Lee-Lee (10) and Verónica C. Trujillo-González (10 ${ }^{b}$ \\ aDepartamento de Filología Hispánica, Clásica y de Estudios Árabes y Orientales, Universidad de Las \\ Palmas de Gran Canaria, Las Palmas de Gran Canaria, Spain; 'Instituto Universitario de Análisis \\ y Aplicaciones Textuales (IATEXT), Universidad de Las Palmas de Gran Canaria, Las Palmas de Gran Canaria, \\ Spain
}

\begin{abstract}
This paper revisits, from a historiographical perspective, the Grammaire de la langue chinoise orale et écrite (1873-76) by French missionary Paul Perny, a fundamental and representative work of French missionary linguistics of the 19th century which, over the years, fell into oblivion. As a missionary grammar, we should also place it in a context of profound changes in which academic sinology strongly emerges under the auspices of French political interests in China. Moreover, through the study of several sources we will show how this work was received by the academic sinologists contemporary with Perny. This will allow us to address the relationship that this missionary linguist had with them. This research also focuses on another aspect, related to Perny's stance on the academic discussion dealing with the alleged inferiority of Chinese with respect to inflected languages, which was a widespread idea at that time.
\end{abstract}

\section{KEYWORDS}

Chinese; grammar; missionary linguistics; French sinology; isolating languages

\section{Introduction}

After spending more than twenty years in China, the Catholic missionary Paul-Hubert Perny (1818-1907) returned to France in 1868, where, five years later, he would publish the first volume of his Grammaire de la langue chinoise orale et écrite, devoted to the spoken language. This would be followed by the second volume in 1876, which dealt with the written language.

Among the grammarians of Chinese of that time, Perny is probably 'un sinologue oublié' (Charbonnier 2014, 41). References to his grammar in current academic literature are relatively scarce too. However, we can highlight the description given by Casacchia and Gianninoto (2012, 590-593), as well as Lanciotti's (2005) paper, which also describes Perny's work but focuses on the second volume of the grammar and emphasises the long 'academic silence' (469) around the sinological contribution of its author. In our view, nevertheless, Perny's grammar is of special interest both for linguistic historiography and for missionary linguistics, since several representative features of the French sinology of that period converge in it, which we will deal with throughout this paper. 
The 19th century is a fundamental era for the development of sinology, especially of French sinology. In this period, a state of maturity is reached with regard to the knowledge of the Chinese world and its language. Proof of that is the important rise of grammars - more than thirty $^{1}$ - which are published in these years in contrast to previous times. Moreover, one of the key characteristics of this period is that knowledge of the Chinese language is no longer essentially dominated by Catholic missionaries ${ }^{2}$ and it is definitely consolidated as an academic discipline practised within the framework of official secular institutions such as the Collège de France ${ }^{3}$ and the École spéciale des langues orientales vivantes.

However, this progress in Chinese studies did not only happen due to a purely academic evolution of the discipline. Various political events, in particular the successive peace treaties signed as a consequence of the defeats of the Chinese Empire in the two Opium Wars, meant a shift in the power relations between China and the Western countries in favour of the latter. Eventually, this promoted an increase in sinological studies, seen as necessary both to instruct personnel to be competent in the management of the diplomatic and commercial interests in Chinese territories and to train missionaries.

The fruitful work done by the Jesuits in the 16th and 17th centuries dwindled after the prohibition - through the well-known Kangxi Imperial Decree in 1721 - of all missionary activities. The political circumstances of the 19th century already mentioned, however, forced the Chinese court to modify its stance of rejection of Christianity, which led to a renewed prominence of the Catholic mission, but also to the definitive establishment of the English-speaking Protestant mission in China, which was relatively new.

In the case of France, this nation took a prominent role as protector of the interests of the Catholic mission, which contributed to a significant French missionary presence in Chinese territories, as well as to the creation of favourable conditions for the emergence of linguistic works produced by Catholic missionaries. ${ }^{4}$ Therefore, in our view, Perny's grammar can be considered as a representative work of the linguistic studies conducted by the Catholic missionaries of that period.

Thus, the present study locates Perny's Grammaire de la langue chinoise orale et écrite (1873-76) in the aforementioned contextual framework and also intends to highlight the efforts of this author, whose body of work is, arguably, one of the most important within the French missionary sinology of the 19th century. Likewise, we will examine the position adopted by this sinologist in the academic discussion with his lay colleagues and how his work was received by the latter.

Moreover, it should be noted that one of the most remarkable aspects of the academic literature in this period is the existing prejudice about the Chinese language, in particular that relating to its supposed inferiority in relation to Indo-European languages. In this paper, we will also tackle Perny's position with regard to these remarks, which were frequently supported with opinions from comparative linguistics, a field developed in Europe almost in parallel with the consolidation of sinological studies as an academic discipline.

\footnotetext{
${ }^{1}$ This figure reflects the results of our searches in the collections preserved both at the Bibliothèque Nationale de France and at the library of the Collège de France.

${ }^{2}$ The Catholic missionaries were responsible for the publication of most of the works related to Chinese from the 16th century to the end of the 18th century.

${ }^{3}$ On 29 November 1814, Louis XVIII signed the Decree whereby the first European Chair of Chinese and Manchu studies was created in France.

${ }^{4}$ On the issue of the French religious protectorate, see Young, Ernest P. (2013).
} 


\section{Perny's grammar as a representative work on Chinese of 19th-century French missionary linguistics}

A survey of the compilation of the main Chinese grammars created before the 19th century reveals the predominance of authors that were Catholic missionaries. This is the case of Arte de la lengua Chio Chiu (1620-21), ${ }^{5}$ the oldest known extant grammatical analysis of Chinese language written by a Westerner (Klöter 2011, 3), as well as Grammatica Linguae Sinensis (1652-1656) by Martino Martini, Arte de la lengua mandarina (1682) by Francisco Varo and Notitia Linguae Sinicae by Joseph Prémare, published in 1831, but written much earlier, in 1728. To these works we should add Arte y vocabulario de la lengua china by Augustinian Martin de Rada and Arte de la lengua china by Dominican Luis Cobo, which have not been preserved, but would date back to the end of the 16th century (Chappell \& Peyraube 2014, 113).

Among the texts written in the 18th century, the key grammar work is, without a doubt, that previously mentioned, written by Jesuit Joseph Prémare, although the grammars by two lay authors also belong to this century: Museum Sinicum (1730) by German Gottlieb Siegfried Bayer and Linguae Sinarum Mandarinicae Hieroglyphicae Grammatica Duplex (1742) by the Frenchman Étienne Fourmont. The corresponding works by Bayer and Fourmont must be regarded, however, as less influential, since the former is a revised translation into Latin of the Arte de la lengua Chio Chiu and the latter is a translation, also into Latin, of Francisco Varo's grammar (Chappell \& Peyraube 2014, 120).

Nevertheless, as we have pointed out, Catholic missionary sinology would lose its leading role by the beginning of the 19th century. Thus, in contrast to the missionary predominance of the previous centuries, the 19th century is characterised by the development and consolidation of academic sinological studies. Indeed, the creation of a Chair of Chinese at the Collège de France in 1814 with Abel-Rémusat (1788-1832) as its first appointment institutionalised and fostered the secularisation of Chinese studies in France. Besides, this process was reinforced in 1840 with the creation of another Chair, focused on the research and teaching of modern Chinese, at the École spéciale des langues orientales vivantes, first held by Antoine Bazin (1799-1862). ${ }^{6}$

Therefore, the grammars and treatises about Chinese published by lay scholars clearly dominate the scenario of French sinology in the 19th century: Eléments de la grammaire chinoise (1822) by Jean-Pierre Abel-Rémusat; Manuel pratique de la langue chinoise vulgaire (1846) by Louis Rochet; Grammaire mandarine, ou Principes généraux de la langue chinoise parlée (1856) by Antoine Bazin; Syntaxe nouvelle de la langue chinoise fondée sur la position des mots (1869) by Stanislas Julien or Cours graduel et complet de Chinois parlé et écrit (1876) by Michel-Alexandre Kleczkowski are the most remarkable examples that precede or are contemporary to Perny.

Another noteworthy characteristic of this century is that, at the same time, the rise of English-speaking sinology takes place, started by the Protestant missionaries sent to China. Some important examples - regarding grammars - are Joshua Marshman with

\footnotetext{
${ }^{5}$ Some scholars believe the Spanish Dominican Melchior de Mançano to be the author of this early grammar (Chappell \& Peyraube 2014, 108). However, Klöter $(2011,8)$ claims that the existing proofs for Melchior de Mançano's authorship are not enough, though he subscribes to the view that a Spanish missionary must be the author.

${ }^{6}$ Concerning the process and the particular circumstances that led to the creation of a second Chair of Chinese at another centre of Higher Education, see Bergère and Pino (1995).
} 
his work Elements of Chinese Grammar (1814); A Grammar of Chinese language (1815) by Robert Morrison; A Grammar of the Chinese Language commonly called the Mandarin Dialect (Edkins [1857] 1864) by Joseph Edkins or Calvin Wilson Mateer and his A Course of Mandarin Lessons, based on Idiom (1892), among others.

In contrast, the compilation of Chinese grammar treatises written by Catholic missionaries suffers from the opposite effect and these become a minority. It is only really worth mentioning two: Arte de China constante de Alphabeto e Grammatica (1829), whose author is the Portuguese Lazarist missionary Joaquim Afonso Gonçalves, specifically aimed at missionaries (Levi 2006, 10) proficient in Portuguese; and, in the francophone realm, Grammaire de la langue chinoise orale et écrite $(1873,1876)$ by Paul Perny.

In Perny's grammar three main features converge, which missionary linguistics, as an academic discipline, regards as characteristic of its objects of study: the language studied does not belong to any of the European languages, its author is a Christian missionary, and its purpose is clearly didactic (Hernández 2013, 223). In terms of the last characteristic, Perny's work stands out due to his numerous didactic comments. In them, the missionary advises to the reader about the best way to learn the language. What is most remarkable about his approach is his encouraging attitude, which makes learning Chinese more accessible. Hence, in contrast to the widespread arguments about the great difficulty entailed in the study of this language, Perny highlights those aspects of Chinese that are less difficult to learn:

La langue chinoise n'a ni déclinaison ni conjugaison, ce qui aplanit énormément la difficulté d'une langue. L'ordre des mots dans la phrase est toujours fixe et régulier. Les règles de la syntaxe sont également régulières et bien peu nombreuses $(1873,8)$.

Moreover, Perny's grammar also mirrors his colonial time, since teaching European languages to native seminarists now becomes a part of missionary work, ${ }^{7}$ unlike that of his predecessors. During his stay in China, one of his responsibilities was precisely as Head of the Liuchongguan seminary, aimed at training native priests. Together with contents related to theological matters and to Chinese, that training obliged seminarists to learn Latin and French, which was something that Perny himself had strongly emphasised (Zhang 2002, 58).

Therefore, in his Grammaire de la langue chinoise orale et écrite, we find examples that prove his didactic work as a teacher of European languages in China. In the following example, we can see how he explains the difficulty for Chinese natives when learning the correct pronunciation of different Latin phonemes:

Les Chinois ont plusieurs articulations qui nous manquent, de même que nous en avons qu'ils n'ont pas. Ainsi, les sons des lettres latines B, D, R, X, Z, ne se trouvent pas dans leur langue. Un Chinois les prononcera par les sons des lettres suivantes: P, T, L, S, S. Il ne pourrait donc prononcer avec facilité les mots latins: Baptizo, Donec, Roma, Xaverius, Zoophytus. $(1873,35)$

\footnotetext{
${ }^{7}$ Teaching French and its culture is a typological element of the Catholic evangelization process with the return of missionaries to China, inextricably linked with the role of France as a prominent Western power in the area; the creation of the Université l'Aurore at the beginning of the last century in Shanghai, where French was the language of instruction, would be the most relevant consequence of that approach. See, for instance, Jean Paul Wiest (2001, 34-58).
} 


\section{Reception and impact of Grammaire de la langue orale et écrite by P. Perny}

In the introductory words to the first volume of his grammar, Perny writes that he decided to publish in advance the first volume, dedicated to the spoken language, without waiting to do so together with the second - the one devoted to the written language -, thus satisfying the demands of 'sinologues distingués' (1873, I). However, Perny does not say explicitly who these were exactly, although he does reveal that the first volume was well received by the public. Therefore, according to the data provided by the author himself (1876, VIII), up to that moment, more than six hundred copies of the first volume had already been sold without advertising it. As for the impact of his work among contemporary grammarians, there are some references that are interesting inasmuch as, besides reflecting their opinion about Perny's work, they also offer a glimpse of the underlying nuances in the relationship between both schools: that of the missionary linguists and that of the academic scholars.

An initial, very positive, appraisal is found in Cours graduel et complet de Chinois parlé et écrit published in 1876 and written by Count Michel Alexandre Kleczkowski, professor of Chinese at the École spéciale des langues orientales vivantes. Even though Kleczkowski does not mention Perny when it comes to pointing out the works of the French sinologists he regards as the most prestigious - Abel-Rémusat, Stanislas Julien, Antoine Bazin - (1876, LX), he does so in a subsequent chapter where he recommends to the students of Chinese three grammars (92), namely:

Quant au choix d'une grammaire, supposé qu'il en faille absolument une, nous recommanderons les Éléments de la Grammaire chinoise par Abel Rémusat, et la Grammaire de la langue chinoise par Paul Perny. Mais nous signalerons surtout le premier volume de la Syntaxe Nouvelle de feu [sic] Stanislas Julien. ${ }^{8}$

In this way, Kleczkowski grants to Perny's work the honour of standing alongside two leaders of 19th-century academic sinology. ${ }^{9}$ Even more significant are the remarks about Perny's grammar provided by German sinologist Georg von der Gabelentz first appointed Chair of Oriental Languages at Leipzig University - in his paper Beitrag zur Geschichte der chinesischen Grammatiken from 1878. The part corresponding to Perny's grammar takes up five pages of the whole paper. In them, the German linguist dissects what he considers is both well and less well accomplished in this work. With reference to the first volume, for instance, he states that, in general, it is a thorough and detailed work with a correct structure; he criticises, however, the excessively free translation of many examples into French, when a Latin version closer to the Chinese version would have been more useful for a beginner $(1878,631)$. Discussing each one of Gabelentz's reflections is not appropriate here; nevertheless, we reproduce one that is representative of the whole paper (630):

Dieses umfängliche, ausserordentlich schön ausgestattete Werk ist zunächst für die Vorbildung der Missionäre bestimmt und dem entsprechend ohne wissenschaftliche Ansprüche nach rein praktischen Gründen verfasst.

\footnotetext{
${ }^{8}$ Given the year of publication of his own work, we must assume that Kleczkowski was probably referring only to the first volume of Perny's grammar, since the second, devoted to the written language, appeared in 1876.

${ }^{9}$ Note, for example, how Austrian Stephan Endlicher considered in his Anfangsgründe der chinesischen Grammatik that Abel-Rémusat and Stanislas Julien were the founders of scientific sinology and responsible for its rapid development $(1845, \mathrm{~V})$; or Louis Rochet, who does the same in his Manuel pratique de la langue chinoise vulgaire (1846, XI).
} 
That is to say, Gabelentz takes for granted that Perny's grammar is conceived, first of all, for the formative instruction of missionaries, which is essentially practical in nature; and - what is most striking - that it does not aspire to be a scientific work. However, Perny's intention when devising his work goes beyond writing a handbook for missionaries to learn the Chinese language. Not for nothing, Perny makes clear $(1873,44)$ that 'Le but principal de cet ouvrage est de vulgariser la langue chinoise. Ce but sera en grande partie atteint dès qu'on aura dissipé les erreurs et les préjugés répandus sur cette langue'. That is, Perny does not intend his work to be essentially addressed to missionaries, but he aspires to join an academic discussion about the true nature of the Chinese language. From the perspective of the present work, based on linguistic historiography, the significance lies not so much in the pertinence of Gabelentz's assessment, but more in how the peculiar relationship between academic and missionary sinology is manifested, the former intending to distance itself in some way from its old masters, the Catholic missionaries. This seems to happen as well when Gabelentz (1878) indicates 'Gleich Prémare und Gonçalves glaubte der Verfasser seine Schüler zunächst in der Umgangssprache heimisch machen zu müssen, ehe er sie in die höhere und ältere Stilform einweiht' classifying Perny's work and those by the other two missionaries into a type of grammar of their own. In that sense, Gabelentz implies that Perny's work and the other two Catholic grammars share common features such as their alleged merely didactic purpose. According to him, this leads them to begin their grammars always with the description of what he calls the 'colloquial style' before moving on to the classical written style $(1873,630) .{ }^{10}$

In contrast, Perny's work, as we have pointed out, does aspire to join the academic discussion of his time. Therefore, its author, apart from addressing the most delicate matters related to the myths about the difficulty and the limitations of the Chinese language, also echoes several grammar authors, among whom Abel-Rèmusat and Prémare stand out. In his preface to the first volume he resorts to the former, for example, to explain the persistence of several prejudices and incorrect ideas about Chinese (1873, 7-10). Moreover, he also quotes Prémare to encourage beginner sinologists. More specifically, he recommends following the example of that author and learning by heart, every day, some lines of the four classical books as an effective strategy for the gradual internalisation of the expressions of Classical Chinese (23). In this same vein of encouragement for young sinologists, and turning to Prémare as well, Perny explains that the pronunciation of Chinese tones is not much harder than the correct prosodic pronunciation of Latin verses (29).

Grammaire de la langue chinoise orale et écrite does not lack references to contemporary sinologists either, regardless of whether they were academic or missionary. That is the case of Protestant missionary Joseph Edkins, to whom Perny alludes with regard to a possible connection of the monosyllabic features of the Chinese language with the use of Chinese characters $(1873,6)$. Another example is Stanislas Julien, an advanced student of Abel-Rémusat and his successor as Chair of Chinese at the Collège de France, to whom Perny makes explicit reference in his preface to the second volume, when he

\footnotetext{
${ }^{10}$ Georg von der Gabelentz himself is the author of a grammar published in 1881 and entitled Chinesische Grammatik mit Ausschluss des niederen Stils und der heutigen Umgangssprache, which, as the title indicates, excludes the vulgar style and the spoken language of his time.
} 
expresses his general acknowledgement of all the works he consulted 'On trouve de bonnes choses dans les ouvrages publiés [...] sur la langue chinoise depuis l'informe Museum sinicum de Bayer jusqu'au livre le plus récent sur cette matière, la Syntaxe chinoise de M. Stan. Julien' (1876, VI).

However, the treatment Perny gives to Julien, who had already passed away, is not always so kind. Thus, when he affirms with an ironic tone that 'Nous n'avons pas eu, comme certain sinologue, l'heureuse chance de découvrir une règle de position nouvelle, qui du donnât du relief à notre œuvre' $(1876, \mathrm{~V})$ it seems quite evident that when Perny mentions a 'certain sinologue' he is referring to Stanislas Julien, since he had published his well-known grammar Syntaxe nouvelle de la langue chinoise in 1870, shortly before Perny's. The controversial hint behind Perny's remark lies in the fact that the syntactic rules of position in Chinese - to which the title of Julien's work precisely refers - as an identifying mechanism of the grammatical categories of words had already been formulated, in particular by British missionary Joshua Marshman in his Elements of Chinese Grammar. Even though Julien gave credit to Marshman, he had added in his Syntaxe nouvelle that 'Malheureusement, ce savant n'a pas su la demontrer' (Julien 1869, VIII). The idea of introducing what was already known as a new grammar rule was considered by Perny as inappropriate, and he considered it important to condemn it in his preface. Here he takes up once more a very critical stance toward Julien, which Perny had previously made public under the pseudonym Leon Bertín, and covered in a more combative tone, in a pamphlet entitled Le charlatanisme littéraire dévoilé, ou la vérité sur quelques professeurs de langues étrangères à Paris (1874). In it, Perny, on the one hand, reproached the deceased Julien for his academic arrogance and, on the other, warned against the lack of competence of some professors of Chinese at the College de France. This criticism from Perny was not unnoticed by Georg von der Gabelentz $(1878,632)$ who censured Perny for the way the latter based much of his work on Julien's grammar, while simultaneously speaking badly of him in public.

The controversy outlined here is just another small sample of the consequences of the return of the Catholic missionaries to China and of their reincorporation to the academic discussion about the Chinese language, which initiated a dialogue, that varied in degrees of harmony, with university sinologists and the emerging English-speaking school.

\section{Defence and illustration of the Chinese language: a common cause}

As had occurred earlier with the members of the Pléiade, led by du Bellay, ${ }^{11}$ the prejudices about Chinese and its inferiority with regard to the Indo-European languages worked the miracle of uniting an important number of academic and missionary sinologists, both Catholic and Protestant, in a common cause. Hence, in spite of the dispute in which both sides were engaged, a common position was tacitly adopted when it came down to proving the value of Chinese.

The initial perception of China and its language was strongly influenced by the descriptions which the first Jesuits sent to Europe. They transmitted a highly positive view of a Chinese civilisation based on a civil and rational morality: the Confucian.

\footnotetext{
${ }^{11}$ The work Défense et illustration de la langue française (1549) is a manifesto which advocates, among other issues, the use of French, both in literary and in scientific works, as opposed to the traditional use of Latin.
} 
However, admiration for China and its language would turn to contempt from the middle of the 18 th century. ${ }^{12}$

This tendency - going back to Perny's time, and fostered by the Chinese military defeats in the Opium Wars - culminates in positions which directly assert Chinese intellectual inferiority. In turn, studies in the thriving field of comparative linguistics, introduced since the beginning of the 19th century by Franz Bopp and August Schleicher, focused their attention on the common origin of the Indo-European languages. This stance brought with it the conclusion that isolating languages, such as Chinese, represented a primitive stage in the evolution of languages, while inflected languages were those that had reached maturity. As expected, the Chinese grammars belonging to Perny's period did not avoid this debate and many sinologists devoted part of their efforts to refuting those arguments which, based on the conclusions of the IndoEuropean school, rushed to discredit Chinese.

Therefore, for example, to counter the criticism expressed by Wilhelm von Humboldt concerning the absence of indicators of grammatical class in Chinese words, Antoine Bazin wrote in his Grammaire mandarine: 'Tout cela est vrai de la langue écrite, mais la langue écrite, encore une fois, n'est qu'un idiome artificiel et de convention; le mot écrit a sa forme, le mot parlé a la sienne' (1856, XIII). That is to say, Wilhelm von Humboldt limited his study to Classical Chinese, without taking into account the linguistic characteristics of Modern Chinese, which does possess more explicit mechanisms for grammatical cohesion than the classical language.

Together with purely linguistic matters, another of the battles fought by these sinologists against their contemporaries was the tone of cultural superiority which was frequently blended into the discourse of some linguists. For that purpose, one of the most solid arguments used by sinologists against these linguists was, precisely, their insufficient knowledge of Chinese.

In this way, the Protestant missionary Joseph Edkins also felt obliged to try to counterbalance these prejudices in his work A Grammar of the Chinese Colloquial Language:

That scholars of high reputation still form erroneous views of the Chinese language, may be seen in the manner in which Dr. K. F. Bekker [sic] speaks of it [...]. He says: "[...] But the whole organic structure of these languages is less perfect than that of inflectional languages having inflections. Yet" he continues, "philology may obtain valuable illustrations from abnormal languages just as physiology gains information from misshapen organisms in the animal world".

A better acquaintance with the Chinese language will probably lead to the abandonment of such words as 'abnormal' and 'misshapen' in the description of it. ([1857]3, III)

As for Perny, we must point out that he also joined this common cause to claim for Chinese the same legitimacy that was granted to inflected languages. Thus, in the preface to his grammar he first praised the works of new linguists such as Franz Bopp, Eugène Burnouf or Max Müller, following the rhetorical canons, and then went on to address their bias. Perny does not hesitate to denounce that bias when

\footnotetext{
${ }^{12}$ Concerning the changes in the perception of China and its language, see respectively Cheng (2014) and Gianninoto and Casacchia (2017), as well as Mungello ([1999] 2013).
} 
some theorists state the linguistic and intellectual superiority of societies with inflected languages:

Cependant il nous semble que ces savants, épris d'une admiration peut-être trop exclusive en faveur des langues de flexion, décernent à ces dernières, d'une manière trop absolue, la palme sur toutes les autres. Leur argument palmaire est que les langues à flexion sont l'apanage exclusif des peuples qui de tout temps auraient marché à la tête de la civilisation. Les anciens peuples n'ont pas été moins civilisés que nous, bien que les langues à flexion leur fussent inconnues. $(1873,5)$

Perny understands, moreover, that the lack of quality and the scarcity of available data about Asian languages should be reason enough to avoid making hasty judgements about them. To solve this situation, the sinologist recommends delving into the research on the barely studied languages of Tibet and Nepal, whose connection with Chinese started to be discerned in the 19 th century $^{13}$ :

L'Orient [...] offre encore de nos jours un champ immense aux études philologiques. Ce champ nous semble encore peu exploré, comme la géographie de ces hauts sites de l'Asie, où fut le berceau du genre humain. On a jugé quelques langues de l'Asie sur les rapports de gens peu sérieux, sur des traductions pâles et décolorées d'ouvrages orientaux. Est-il possible de porter un jugement sérieux sur une langue d'après de semblables données ? $(1873,5)$

Once these general remarks on the state of affairs were made, Perny focuses his criticism on specific authors. Thus, Perny cannot but criticise the strong statements made by French historian and philologist Ernest Renan when he puts forward his opinion about Chinese in the following way:

La langue chinoise [...] avec sa structure inorganique et incomplète, n'est-elle pas l'image de la sécheresse d'esprit et de cœur qui caractérise cette langue ? Suffisante pour la technique des arts manuels, pour une littérature légère de petit aloi, pour une philosophie qui n'est que l'expression souvent fine, mais jamais élevée, du bon sens pratique, la langue chinoise exclut toute philosophie, toute science, toute religion [...]. (As quoted in Perny 1873, 12).

To invalidate these assertions, Perny makes use of irony and, just as Edkins did, warns against Renan's deep ignorance of the Chinese language:

Voilà un jugement si affirmatif sur la langue chinoise que tout lecteur en tirerait la conclusion que M. Renan es très-versé dans la connaissance de cette langue. Cet auteur, pourtant, ignore complétement la langue chinoise. Nous pourrions relever vingt autres passages aussi erronés que le précèdent sur la même langue, dans le même ouvrage. $(1873,12)$

Renan's boldness is likewise depicted through the following reflection by Perny:

Pour parler pertinemment de la structure d'une langue, ne faut-il pas la connaitre au moins convenablement ? Si on ne la connait pas, est-il possible de pouvoir parler de sa littérature, de sa philosophie ? $(1873,12)$

Another recipient of Perny's criticism is François Guinand, linguist and author of Origine de l'alphabet, published in 1868. Perny presents a long quote in which this philologist, with regard to Chinese, concludes 'Cette langue d'enfant, ébauche informe de la parole, au service d'une pensée adulte et pleine, condamnait l'homme à une dure

\footnotetext{
${ }^{13} \mathrm{As}$ is well known, current comparative linguistics does indeed confirm that Chinese belongs to the family of SinoTibetan languages.
} 
gymnastique intelectuelle' (as quoted in Perny 1873, 12). Guinand next presents his arguments on the limitations of the Chinese lexis but falls into the error of taking the phonetic repertoire of syllables in Chinese ' 450 syllabes' as elements that are combined with the '214 clefs' - that is, the radicals of Chinese writing - . Hence, to calculate the total number of words and Chinese characters ' 80 mille mots', Guinand mixes the phonetic level with that of writing, arriving at the incorrect conclusion that the Chinese language 'ne peut plus ajouter un mot à son Vocabulaire, et une conception à son entendement' (as quoted in 13). To this categorical statement, Perny answers laconically 'L'auteur confond sans cesse les syllabes, les mots avec les caractères de l'ecriture' (1873, 13), to reveal Guinand's deficiencies with respect to Chinese.

Another of the prejudices which had to be challenged in the 19th century was the alleged intellectual inferiority of the Chinese people. Thus, Perny shows special disagreement with judgements made about the mental aptitude of the Chinese people, derived from a superficial description of their language, even when these are penned by another clergyman. That is the case of Alfred Jean Gilly, prelate of Nîmes, who in 1865 writes in his work La Science du langage:

La proposition chinoise, privée d'unité, ne connait aucun de ces enroulements synthétiques qui forment le discours. Le Chinois ne peut suivre sa pensée dans ses nuances et dans son étendue. Obligé de la revêtir d'une expression uniforme et invariable, la vie manque au début du discours; le Chinois s'arrête essoufflé (...) N'ayant pas de classes de mots déterminés, les mots de cette langue sont sans vie, sans mouvement, sans couleur et sans forme...La Chine est la patrie par excellence de l'abstraction. [...] L'athéisme répond à la forme des langues chinoises. (As quoted in Perny 1873, 13 - 14).

Gilly's words are an expressive example of how the perception projected by the discussion about the alleged limitations of Chinese at the beginning of the century did not show signs of diminishing in Perny's time, but, on the contrary, had expanded into the most diverse areas - in this case, the religious - . Perny's answer to Gilly is concise:

Tout sinologue qui lira les extraits précédents ne reviendra pas de son étonnement. Il est impossible, en effet, d'accumuler en moins de mots autant d'erreurs sur une langue. C'est ainsi que se perpétuent les préjugés, cent fois combattus, contra la langue chinoise. $(1873,14)$

Perny emphasises once more the lack of knowledge about the most elementary questions of Chinese in order to refute Gilly's conclusions. However, he introduces a fresh nuance when confirming the tenacious persistence of these prejudices in spite of the abundant sinological studies which - with a new and more differentiated appreciation of the nature of Chinese - were being published in that century.

\section{Conclusions}

With his Grammaire de la langue chinoise orale et écrite, Paul Perny takes over from the works produced by the old missionaries in China, pioneers of Western sinology. However, he differs from them because his work represents a missionary linguistics within a colonialist framework, that of the return of the French Catholic missionaries to China under the protection of the peace treaties resulting from the Opium Wars in the middle of the 19th century. The emergence of linguistic studies about Chinese in this century is related to this new political framework as well. These studies, however, are no 
longer led by Catholic missionaries. It should be noted, nevertheless, that, among the abundant production of Western grammars of the Chinese language published in the second half of the 19th century, Perny's is the only relevant grammar that can be attributed to Catholic missionary linguistics; the rest of them belong to either authors from secular academic sinology, or to authors that come from the thriving Englishspeaking Protestant missionary sinology.

The reception of Perny's work among the sinologists of his time is another of the reasons that denotes its importance. There are contemporary lay authors such as Michel Kleczkowski or Georg von der Gabelentz who praise him. However, the latter author insists on drawing an epistemological difference between the works coming from missionary linguistics - to which he assigns Perny's study - with a pure didactic purpose aimed at training missionaries, and those from academic research which are truly scientific.

Perny expresses his acknowledgement of the contributions made by his colleagues, although he subtly shows his disapproval of some professors of Chinese at French academic institutions, among whom Stanislas Julien can be identified. These criticisms are the reflection of the particular nature of the relationships between this missionary sinologist, trained by spending many years in China, and university sinology.

Moreover, Perny's grammar mirrors the 19th-century debate on the nature of Chinese, which some scholars - in line with the theories of the emerging discipline of comparative linguistics - situate at a lower evolutionary level than the inflected languages. Perny's rebuttals mainly focus on the insufficient or incorrect knowledge of Chinese that was the basis for such statements which, moreover, paid no attention to the new studies published about the language. Furthermore, regarding the origins of Chinese and its relationship with other languages, it is worth pointing out his correct intuition when adopting the position of those who began to discern the links between Chinese and the languages in the Tibetan Plateau.

Therefore, Paul Perny's grammar is a work whose pages reflect a highly significant period in the history of Western sinology and, in particular, of French sinology. It should also be concluded that Perny's work is representative of a French Catholic missionary sinology which, taking over from the efforts of its predecessors, begins a new journey.

\section{Disclosure statement}

No potential conflict of interest was reported by the authors.

\section{Notes on contributors}

Xavier Lee-Lee is a lecturer of the Department of Hispanic and Classical Philology and Arabic and Oriental Studies at the Universidad de Las Palmas de Gran Canaria, where he has been teaching German and Translation and, at present, is teaching Chinese. His research interests lie in travel reports written by 19th century German speaking naturalists as well as in the area of linguistics, focusing on the comparative study of Chinese and Spanish grammar structures and the history of missionary linguistics in China.

Verónica C. Trujillo-González is a lecturer of the Department of Modern Philology, Translation and Interpretation Studies at the University of Las Palmas de Gran Canaria, where she teaches in 
the area of French Philology. Her research focuses mainly on the study of monolingual and multilingual French lexicographical works, both from a synchronic and diachronic perspective and with a special interest in the first multilingual dictionaries of French with the Chinese language. Her work has been published in national and international journals and in collective works. She is also part of the research group "Variation and Linguistic Change" of the "Instituto de Análisis y Aplicaciones Textuales (IATEXT) (the Institute for Textual Analysis and Applications)" where she is responsible for the research line of Lexicography, Lexicology and Translation.

\section{ORCID}

Xavier Lee-Lee (D) http://orcid.org/0000-0003-4100-5986

Verónica C. Trujillo-González (D) http://orcid.org/0000-0003-3492-8061

\section{References \\ Primary sources}

Abel-Rémusat, Jean-Pierre. 1822. Éléments de la Grammaire chinoise ou principes généraux du Kou-wen ou style antique, et du Kouan-hoa, c'est-à-dire, de la langue commune généralement usitée dans l'empire chinois. Paris: Imprimerie royale.

Bazin, Antoine-Pierre-Louis. 1856. Grammaire mandarine, ou principes généraux de la langue chinoise parlée. Paris: Imprimerie Impériale.

Edkins, Joseph. [1857]1864. A Grammar of the Chinese Colloquial Language Commonly Called the Mandarin Dialect. 2nd edition Shanghai: Presbyterian Mission Press.

Endlicher, Stephan Ladislaus 1845. Anfangsgründe der chinesischen Grammatik. Wien: Carl Gerold.

Gabelentz, Georg von der. 1878. "Beitrag zur Geschichte der chinesischen Grammatiken und zur Lehre von der grammatischen Behandlung der chinesischen Sprache." Zeitschrift der Deutschen Morgenländischen Gesellschaft 32(4): 601-64.

Gabelentz, Georg von der. 1881. Chinesische Grammatik mit Ausschluß des niederen Stiles und der heutigen Umgangssprache. Leipzig: Weigel.

Gonçalves, Joaquim Afonso 1829. Arte De China Constante De Alphabeto E Grammatica: Comprehendendo Modelos Das Differentes Composiçoens. Macao: Real Collegio de San Jose.

Julien, Stanislas. 1869. Syntaxe nouvelle de la langue chinoise fondée sur la position des mots, suivie de deux traités sur les particules et les principaux termes de grammaire, d'une table des idiotismes, de fables, de légendes et d'apologues traduits mot à mot: Premier volume. Paris: Librairie de Maisonneuve.

Kleczkowski, Michel-Alexandre. 1876. Cours graduel et complet de chinois parlé et écrit: Volume 1. Phrases de la langue parlée tirées de l'Arte China du P. Gonçalves. Paris: Maisonneuve et Cie.

Marshman, Joshua. 1814. Elements of Chinese Grammar: With a Preliminary Dissertation on the Characters, and the Colloquial Medium of the Chinese, and an Appendix Containing the TaHyoh of Confucius with a Translation. Serampore: Mission Press.

Mateer, Calvin Wilson 1892. A Course of Mandarin Lessons: Based on Idiom. Shanghai: American Presbyterian Mission Press.

Morrison, Robert. 1815. Grammar of the Chinese Language. Serampore: Mission Press.

Perny, Paul. 1873. Grammaire de la langue chinoise orale et écrite. Vol. I. Paris: Maisonneuve \& Cie.

Perny, Paul. 1876. Grammaire de la langue chinoise orale et écrite. Vol. II. Paris: Maisonneuve \& Cie.

Perny, Paul. 1874. Le charlatanisme littéraire dévoilé, ou la vérité sur quelques professeurs de langues étrangères à Paris: Dédié à MM. les Professeurs du Collège de France. Versailles: Beaugrand et Dax. 
Prémare, Joseph. 1831. Notitia Lingua Sinicae. Malacca: Cura Academiae Anglo-sinensis.

Rochet, Louis. 1846. Manuel pratique de la langue chinoise vulgaire. Paris: Firmin Didot Frères.

\section{Secondary sources}

Bergère, Maire Claire, and Angel Pino, eds. 1995. Un siècle d'enseignement du chinois à l'École des langues orientales: 1840-1945. Paris: L'Asiathèque.

Casacchia, Giorgio, and Mariarosaria Gianninoto. 2012. Storia della linguistica cinese. Venezia: Libreria Editrice Cafoscarina.

Chappell, Hilary, and Alain Peyraube. 2014. "The History of Chinese Grammars in Chinese and Western Scholarly Traditions." Language and History 57 (2): 107-36. doi: 10.1179/ 1759753614Z.00000000032

Charbonnier, Jean. 2014. “Paul Hubert Perny (1818-1907) 童保绿, 号文献 missionnaire sinologue converti par la Chine." Missions Étrangères de Paris: Asie et Océan Indien 496: 40-51.

Cheng, Anne. 2014. "Philosophy and the French Invention of Sinology: Mapping Academic Disciplines in Nineteenth Century Europe." China Report 50 (1): 11-30. doi: 10.1177/ 0009445513516533

Gianninoto, Mariarosaria, and Giorgio Casacchia. 2017. "Western Views of the Chinese Language". In Encyclopedia of Chinese Language and Linguistics: Volume 4, edited by Rint Sybesma, 520-27. Leiden: Brill.

Hernández, Esther. 2013. "Aspectos metodológicos de la investigación en lingüística misionera hispánica.” In El mundo indígena desde la perspectiva actual: Perspectivas multidisciplinarias, edited by María del Pilar Maynez, 223-47. México: Grupo Destiempos.

Klöter, Henning. 2011. The Language of the Sangleys: A Chinese Vernacular in Missionary Sources of the Seventeenth Century. Leiden/Boston: Brill.

Lanciotti, Lionello. 2005. “A Forgotten Orientalist". East and West 55 (1/4), 467-71.

Levi, Joseph Abraham 2006. "Padre Joaquim Afonso Gonçalves (1781-1834) and the Arte China (1829): An Innovative Linguistic Approach to Teaching Chinese Grammar". Paper presented at the Fourth International Conference on Missionary Linguistics, Universidad de Valladolid. January 2006. doi: 10.1075/sihols.111.17lev

Mungello, David. 2013. The Great Encounter of China and the West: 1500-1800. 4th edition. Lanham: Rowman \& Littlefield Publishers.

Wiest, Jean Paul. 2001. "Understanding Mission and the Jesuits' Shifting Approaches toward China". In Missionary Approaches and Linguistics in Mainland China and Taiwan, edited by $\mathrm{Ku}$ Wei-Ying, 33-58. Leuven: Leuven University Press.

Young, Ernest P 2013. Ecclesiastical Colony: China's Catholic Church and the French Religious Protectorate. New York: Oxford University Press.

Zhang, Junzhe 张濬哲. 2002. “Guìyáng tiānzhǔjiào Liùchōngguān zhōngxiūyuàn gàikuàng” 贵阳 天主教六冲关中修院概况 [About the Guiyang catholic middle seminary in Liuchongguan]. Guiyáng wén shi 贵阳文史 4, 56-60. 